Archived version from NCDOCKS Institutional Repository http://libres.uncg.edu/ir/asu/

\title{
Appalachľan
}

B O O N E, N O R T H C A R O L I N A

\section{The Future of the Planet in the Hands of MBAs: An Examination of CEO MBA Educationand Corporate Environmental Performance}

\author{
Authors: \\ Daniel J. Slater and Heather R. Dixon-Fowler
}

\begin{abstract}
:
Several critics contend that MBA education is irrelevant to practicing managers (e.g., Mintzberg, 2004), while others suggest it creates a pro fits- first mentality without regard for moral considerations (e.g., Ghoshal, 2005). Based on these criticisms, we explore the implications for CEOs with an M BA degree-specifically, if and how their M BA ed ucation might influence their firms' corporate environmental performance (CEPJ. Extant literature provides conflicting arguments; therefore, we empirically tested the relationship using a sample of 416 S\&P 500 CEOs and found a significant positive association between CEOs with $\mathrm{M} B A s$ and CEP, even alter accounting for several firm- and individual-level characteristics. In addition, post-hoc analysis revealed that the MBA program ranking had no effect on CEP.
\end{abstract}

Daniel J. Slater and Heather R. Dixon-Fowler(2010) "The Future of the Planet in the Hands of MBAs: An Examination of CEO MBA Educationand Corporate Environmental Performance" Academy of Management Learning \& Education, Vol. 9, No. 3. pp.429-441. version of Record Available@ (http://www.jstor.org/stable/25782028) 


\title{
The Future of the Planet in the Hands of MBAs: An Examination of CEO MBA Education and Corporate Environmental Performance
}

\author{
DANIEL J. SLATER \\ Union University \\ HEATHER R. DIXON-FOWLER \\ Appalachian State University
}

\begin{abstract}
Several critics contend that MBA education is irrelevant to practicing managers (e.g., Mintzberg, 2004), while others suggest it creates a profits-first mentality without regard for moral considerations (e.g., Ghoshal, 2005). Based on these criticisms, we explore the implications for CEOs with an MBA degree-specifically, if and how their MBA ed ucation might influence their firms' corporate environmental performance (CEPJ. Extant literature provides conflicting arguments; therefore, we empirically tested the relationship using a sample of $416 \mathrm{S \& P} 500 \mathrm{CEOS}$ and found a significant positive association between CEOs with $M B A s$ and CEP, even alter accounting for several firm-and individual-level characteristics. In addition, post-hoc analysis revealed that the MBA program ranking had no effect on CEP.
\end{abstract}

Disturbing indictments have recently been levied against business education, particularly against business schools' "mother-ship," MBA programs (Mintzberg, 2005). Some have pointedly critiqued MBA programs as irrelevant to the needs of practicing managers (e.g., Mintzberg, 2004; Pfeffer \& Fong, 2002) providing few, if any, benefits to the recipient or the organization (Dreher, Dougherty, \& Whitely, 1985; Leonhardt, 2000). Others suggest that MBA education does have an effect on the recipient by creating a "profits-first" mentality (e.g., Ghoshal, 2005; Giacalone \& Thompson, 2006). These scholars argue that this indoctrination toward the single-minded pursuit of profits, and accompanying assumptions of opportunism, are at least partly responsible for the recent business scandals and unethical executive actions which frequent the popular press (Henle, 2006).

While these criticisms provide significant cause for concern, one other evokes a potentially cataclysmic consequence-how MBA education could influence environmental sustainability. For exam- ple, Benn and Dunphy (2009) suggest that MBA programs do not adequately prepare graduates to deal with the challenges of sustainability issues in the workplace. Giacalone and Thompson (2006: 268) paint an even darker picture by arguing that our "organization-centered worldview" allows business f aculty to teach a profits-first perspective "without asking students to confront the factually impossible notions of unlimited growth in a world of limited resources, the questionable consumerist ideology based in materialistic goals, and the ecologically unsound tactics that may bring planetary suicide." These indictments are alarming, considering the positions of influence in large corporations occupied by many MBA graduates. While other avenues of environmental sustainability are pursued, perhaps none has a greater influence than that of corporate environmental performance (CEP; e.g., a firm's use of recycled materials, compliance with environmental regulations). As a society, we recognize that the scale and influence of our largest companies are greater 
than that of most nations, and as a result, these firms have a significant impact on our world's natural resources (Samuelson, 2006). Therefore, it is important to ask, what will MBA graduates do with their positions of power over these vast resources?

Based on the recent criticisms of MBA education, the research question we explore here focuses on the relationship between MBA education and CEP---and more specifically the MBA education of the firm's CEO. As primary decision maker (Hosmer, 1982; Mintzberg, 1978), the influence of the CEO is particularly vital. The CEO not only plays a critical role in core business strategies, but also in social and environmental strategies and resource allocation to such pursuits (Agle, Mitchell, \& Sonnenfeld, 1999; Wood, 1991). Based on upper echelons theory (Hambrick \& Mason, 1984), prior research has found that CEO characteristics (e.g.. tenure, functional background, international experience) influence selective perception. interpretations, decision making, and ultimately, firm outcomes including social outcomes (Simerly, 2003; Slater \& Dixon-Fowler, 2009). Extending this line of research, this study considers the various criticisms of MBA education and multiple perspectives on CEP and asks, "What is the relationship between CEO MBA education and CEP?"

By exploring this question, our contribution is threefold. First. we introduce a new research question into the discourses on MBA education and CEP. entailing important implications for both streams of research. Second, we address the assertion that MBA critiques have lacked significant empirical investigation (Pfeffer \& Fong, 2002). To address this issue, we use a sample of 416 CEOs from the S\&P 500 and put to a rigorous test the question of whether CEOs' MBA education predicts CEP. The results of the analysis provide support for some MBA criticisms and contradict others, leading to important implications for educators, business, and society. Finally, our study moves beyond examining individual-level outcomes of education (e.g.. earnings, career trajectory) and examines a long-term organization-level outcome with societal implications for environmental sustainability. By doing so, it empirically examines a higher level outcome of MBA education than previous research currently provides.

\section{BACKGROUND}

Before exploring the potential influence of CEO MBA education on CEP, we review the literature to serve as a backdrop for the ensuing arguments. First, we discuss a few select MBA criticisms. then the two predominant paradigms of CEP. and fi- nally give a brief discussion of upper echelons theory.

\section{MBA Criticisms}

While a review of the entire volume and variety of MBA critiques is beyond our scope here, many of the recent criticisms which contribute to this discourse can be condensed into two categoriesirrelevance and a profits-first mentality.

\section{Irrelevance}

The irrelevance criticisms suggest that MBA education does not provide useful knowledge, skills, or abilities for management, and thus, provides no individual or organizational benefit. Pfeffer and Fong (2002) have suggested that out of a desire to achieve respectability and legitimacy, business schools adopted the ways of social science departments. As a result, research and teaching has moved away from practical relevance to accommodate precision, control. and testable models. These sentiments have been echoed by Mintzberg (2004) who argues that MBA programs simply provide specialized training in functions of business and are unable to contribute to the broader practice of management. He also suggests that management is a craf $t$ that is learned and improved through experience, not in the classroom. Bennis and O'Toole (2005) also chastise business schools for treating management as a science rather than a profession and for hiring and rewarding faculty based on research records and not managerial experience.

Many have suggested that MBA programs focus far too heavily on quantitatively based analytical techniques to the detriment of "soft skills," such as interpersonal and communication skills, which are essential for managers (e.g.. Jenkins \& Reizenstein, 1984; Porter \& McKibbin, 1988; Simpson, 2006). Rubin and Dierdorf (2009) found empirical evidence that supports these arguments, suggesting that competencies such as "human capital management." which are most valued by practicing managers, are underrepresented in MBA programs. Similarly, Navarro (2008) found that the MBA curricula of top-ranked U.S. business schools lack emphasis on "sof t skills." In addition, Navarro (2008) also found the curricula lacked multidisciplinary integration, which leads to the creation of functional silos within business school education. In short. the irrelevance criticisms suggest that the knowledge, skills. and abilities necessary for ef - 
fective management are lacking in MBA education.

\section{Profits-First}

The profits-first criticism is most notably attributed to Ghoshal (2005). who suggested that our overwhelming acceptance of economics-based paradigms, such as agency theory and transaction-cost economics has become a self-fulfilling prophecy, creating graduates who seek profits first. and at any cost. Ghoshal (2005: 76) laments that "by propagating ideologically inspired amoral theories. business schools have actively freed their students from any sense of moral responsibility." Similarly. Giacalone and Thompson (2006: 267) refer to the propagation of an "organization-centered worldview" (OWV) in which business is the foundation of the modern world:

We teach students to perpetuate business' importance and its centrality to society, to do so by increasing wealth ... only in the background are other stakeholders and positions discussed, although generally within this economic context. At the top of our values hierarchy is money and all of its constituents: power, status. and the accumulation of wealth (Giacalone \& Thompson. 2006: 267).

Finally, Mitroff (2004: 185) refers to the creation of "a mean-spirited and distorted view of human nature," which assumes "that at their core humans are completely and entirely ruthless, motivated solely by greed, opportunistic, purely selfish, and it should come as no surprise, totally out for themselves and no one else."

The empirical evidence generally lends support to the prof its-first criticisms (for an exception see Neubaum. Pagell, Drexler. McKee-Ryan, \& Larson, 2009). For example. research suggests that more exposure to economics-based courses-which are founded on profits-first imperatives and assumptions of opportunism-leads to more free-riding (Marwell \& Ames, 1981), less cooperation (Frank, Gilovich. \& Regan, 1993). selfish behavior (Carter \& Irons, 1991), and engaging in corrupt behavior (Frank \& Schulze. 2000). Contributing further evidence are studies finding that MBA students are more likely to cheat in their coursework than nonbusiness student peers (McCabe, Butterfield, \& Trevino, 2006), and the greater emphasis that is placed on financial success, the greater the likelihood to cheat (McCabe \& Trevino, 1995). Perhaps some of the most condemning evidence is findings suggesting that in their pursuit of profits, as a greater proportion of a firm's top management team possesses MBAs. the more a firm engages in illegal activity, such as safety and health violations (Williams, Barrett, \& Brabston. 2000). In short. these criticisms and empirical results support the notion that MBA education creates a profits-first mentality which is pursued without regard for moral considerations or social responsibility.

\section{CEP Perspectives}

CEP assesses a firm's degree of success in reducing and minimizing its environmental impact (Klassen \& McLaughlin, 1996: 1111). Most of ten, the impact is measured by the firm's policies, programs, and observable outcomes (e.g., pollution prevention programs, use of recycled materials, and adherence to environmental regulations) related to the environment (Wood, 1991). As such, CEP is an indicator of a firm's contribution toward environmental sustainability. While the CEP construct is fairly well accepted around the idea of reducing and minimizing impact on the environment. two dominant paradigms divide CEP literature-the normative perspective and the business case. Both perspectives generally share definitions and measures of CEP: it is their fundamental assumptions on the motivation and purpose that differ.

\section{Normative}

The normative case for CEP flows from the modern era of corporate social responsibility (CSR) advocated by scholars such as Bowen (1953), Frederick (1960), and Carroll. (1979). CSR is predicated on the assumption that business has a moral obligation to consider the societal impacts of its decisions and strategies. These sentiments are also seen within most definitions of environmental sustainability, which refer to society's ability to meet our needs today without compromising future generations' ability to meet their own (World Commission on Economic Development, 1987). According to normative arguments, CSR and sustainability concepts focus on what actions should be taken based on moral responsibilities.

The normative case for CEP is also observed in normative stakeholder theory (Donaldson \& Preston, 1995), which makes arguments based on the theory of property and suggests that ownership provides a "limited" set of rights (Coase, 1960). These limited rights are actually relations between individuals (Pejovich, 1990), including protections from harmful uses of property. which requires consideration of others, or non-owners. 
Thus, the "theoretical concept of private property clearly does not ascribe unlimited rights to owners and hence does not support the popular claim that the responsibility of managers is to act solely as agents for the shareowners" (Donaldson \& Preston, 1995: 84). Instead, "property rights give various groups a moral interest. commonly referred to as a stake, in the affairs of the corporation" (Donaldson \& Preston, 1995: 85). In sum, because shareholders do not have unlimited rights, firms have a moral obligation to consider their social and environmental impacts. Thus, the normative perspective views CEP as an end goal in and of itself (Jones \& Wicks, 1999) because contributing to sustainability is a moral and social obligation.

\section{Business Case}

The business case suggests that CEP provides the firm with financial returns, and thus, provides a business-relevant justification for environmental initiatives. Explanations for the returns from CEP are varied. For example, the natural resourcebased view of the $f$ irm argues that pollution prevention, product stewardship, and sustainable development strategies represent key managerial and firm capabilities and resources, which produce a competitive advantage (Hart. 1995). Researchers have also argued that CEP reflects a firm's operational efficiency and capacity for innovation (e.g., Aragon-Correa, 1998; Porter \& van der Linde, 1995). Porter and Kramer (2006) suggest that normative arguments require far too broad of an engagement in social initiatives, and that a firm should selectively choose the specific social issues which present opportunities to create shared wealth. When a firm engages in focused and proactive initiatives that are integrated with their core strategy, a competitive advantage will ensue. Instrumental stakeholder theory also contributes to the business case for CEP, suggesting that engagement in cooperative and ethical behavior reduces agency and transaction costs, enabling a firm to more effectively meet the needs of diverse stakeholder groups (Jones, 1995, Freeman \& Evan, 1990). From an institutional perspective (e.g., DiMaggio \& Powell, 1983; Meyer \& Rowen, 1977) CEP provides legitimacy and reputational benefits to the firm as well (Hart, 1995; Bansal \& Clelland, 2004). Finally, the empirical tests of the relationship between CEP and corporate financial performance (CFP) have largely supported a positive relationship, including several meta-analyses (Dixon-Fowler, Slater, Romi, Johnson, \& Ellstrand, 2009; Orlitzky, Schmidt, \& Rynes, 2003).

\section{Upper Echelons}

Upper echelons theory (Hambrick \& Mason, 1984) serves as the underlying premise for the arguments to be developed below. Based on bounded rationality, upper echelons theory assumes that executives are not able to comprehend and process all available information, but rather situations are perceived with the executives' limited cognitive resources. In addition, the limited information perceived is filtered through an interpretation process influenced by the executive's experiences, values, and personality. These perceptions then influence the choices made, and eventually, firm outcomes. In essence, because the executive is unable to make a completely rational decision based on all available information, their choices ultimately reflect their individual differences. Extensive empirical evidence supports upper echelons theory, including meta-analytic evidence (Certo, Lester, Dalton, \& Dalton, 2006). Moreover, this evidence is not confined to executives' influence over purely strategic results, but also includes social outcomes. Several recent studies have found CEO characteristics, such as tenure, functional background, and international experience, influence a firm's corporate social performance (Simerly, 2003; Slater \& Dixon-Fowler, 2009). Extending this stream of research, arguments will be developed below regarding the potential relationship between CEOs with MBAs and CEP.

\section{MBA EDUCATION AND CEP- COMPETING ARGUMENTS}

Based on the literature review above, reasonable and competing arguments can be made for nonexistent, negative, and positive relationships between CEO MBA education and CEP. Each possibility will be briefly explored.

\section{No Relationship}

The argument for no relationship flows from the irrelevance criticism of MBA education. The irrelevance criticism suggests that MBA programs do not provide the necessary training and education that would assist a CEO in developing effective and profitable CEP strategies. While scholars have argued that integration of environmental sustainability initiatives with a firm's core strategy and the interconnectedness of these strategies are vital for competitive advantage (Porter \& Kramer, 2006; Hart, 1995), critics (Mintzberg, 2004) and empirical evidence (Navarro, 2008) suggest that MBA programs do not 
promote such integration; rather, they remain in functional silos. Beyond integration, effective CEP strategies require successful coordination, communication, and collaboration between multiple functions and departments within the organization, as well as with stakeholders beyond organizational boundaries (Hart, 1995; Welf ord \& Gouldson, 1993). However, the required sof $t$ skills, such as communication and coordination, are those which are most notably lacking in MBA education (e.g., Jenkins \& Reizenstein, 1984; Porter \& McKibbin, 1988; Simpson, 2006).

In addition, the irrelevance criticism suggests that MBA courses do not provide sufficient knowledge or ability to make business-relevant ethical decisions. From the normative perspective, sustainability ef forts such as CEP are a social responsibility that require the ability to evaluate ethical situations and make moral judgments (Madagan, 2008). Practicing managers acknowledge that many ethical business decisions are not black and white, but instead involve multiple vantage points and require complex judgment calls (Lewicki, 2005). However, most MBA programs have no required ethics course (Evans \& Robertson, 2003). Some schools attempt to integrate ethics through the core coursework. which places the responsibility on faculty to integrate ethics into their courses. However, this integration is difficult to monitor (Evans, Trevino, \& Weaver, 2006). Even worse, business school deans indicate that the major impediment to increasing stand-alone ethics courses is a lack of faculty interest (Evans \& Robertson, 2003), which suggests that ethics may not be well integrated into the core courses being taught by the faculty. As a result, not only have MBAs received little training on how to handle ethical issues when they arise, but without such training, they may not even recognize their firm's impact on environmental sustainability as an ethical or moral issue.

Based on the irrelevance criticism, CEOs with an MBA have received little additional training that would enhance their firm's CEP. Many important issues necessary for addressing CEP (e.g., integration, communication, complex ethical judgments) are lacking in MBA education. Thus, a CEO with an MBA degree has little-to-no advantage over CEOs without an MBA in terms of their training for the necessary knowledge and abilities related to CEP. In other words, because the program lacks the relevant content and training, there is likely no relationship between CEO MBA education and CEP.

\section{Negative Relationship}

As opposed to the irrelevance criticism, the profitsfirst criticism does suggest an impact based on MBA education. However, the anticipated direction of the effect differs depending on the CEP perspective (normative or business-case) under consideration. The negative relationship argument flows from the profits-first criticism of MBA education when considering the normative perspective of CEP. The normative perspective suggests that CEP is an obligation, and thus, the motivation for engaging in CEP activities is out of a moral responsibility to society. However, the profits-first criticism suggests that MBA education indoctrinates future executives to consider all decisions in economic terms without regard for ethical considerations (Giacalone \& Thompson, 2006). One of Ghoshal's (2005) primary arguments is that our amoral theories have released students to pursue profits without regard for social responsibility, which has led to many of the recent business scandals and unethical decisions by executives. Ghoshal does not simply imply ambivalence toward ethical decisions, but rather that the assumption of opportunism in our theories creates a self fulfilling prophecy and leads graduates to take advantage of ethically questionable situations, to their own benefit.

Based on the profits-first criticism, MBA education actively creates future executives with a narrow, profit-driven focus and a decreased sense of social responsibility. As Leavitt (1989: 39) asserts, MBA programs create "critters with lopsided brains, icy hearts, and shrunken souls." Thus, MBAs may view the pursuit of corporate environmental initiatives for moral obligatory reasons as inappropriate and irresponsible to the firm and its shareholders. Therefore, given that the motivation to engage in CEP initiatives from a normative perspective is out of a sense of social responsibility, MBA-educated CEOs could be expected to be far less concerned about CEP compared to non-MBA educated counterparts. As opposed to the irrelevance criticisms, the profits-first criticism does suggest an influence of MBA education. From the normative perspective of CEP, the profits-first criticism would suggest a negative relationship between CEO MBA education and CEP.

\section{Positive Relationship}

Although sustainability and environmental issues are not extensively incorporated into the curricula of most MBA programs (Benn \& Dunphy, 2009), when CEP topics are discussed, it is generally 
within an economic context. As Giacalone and Thompson (2006: 268) explain, "virtually everything in our course content is justified by, tied to, or infused with the financial bottom line." In other words, when environmental issues are discussed in business schools, it is not the normative perspective being taught. but rather the businesscase, that profits can be gained from engaging in such activities (Giacalone \& Thompson, 2006). In fact, research has found that business education significantly enhances students' belief that sustainability is an important element of firm perf ormance (Neubaum et al.. 2009). As stated above, the profits-first criticism argues that MBA education creates an organization-centered worldview that promotes the accumulation of wealth above all else (Giacalone \& Thompson, 2006). Thus, Ghoshal's (2005) assertion regarding the self-fulfilling prophecy of opportunism would suggest that MBA graduates will actively seek out and take advantage of any opportunity to create wealth for themselves and their firms-including $C E P$.

From the business-case perspective, the motivation for CEP activities is financial. As the profitsfirst criticism of MBA education suggests, MBA graduates will pursue profits by taking advantage of any opportunity. Moreover, CEOs with an MBA education may be more aware of the business case for CEP from their coursework and are actively trained to seek out the potential economic benefits. Thus, MBA-educated CEOs could make a rational choice to pursue environmental initiatives in an effort to maximize prof its. Based on the profits-first criticism of MBA education, the normative perspective of CEP suggests a negative relationship; however, the business-case perspective of CEP suggests the opposite effect.

\section{Research Question}

The arguments presented above provide contradicting possibilities. The irrelevance criticism suggests there is likely no relationship between CEO MBA education and CEP. The profits-first criticism of MBA education suggests a negative relationship from the normative perspective of CEP, but a positive relationship from the business-case perspective. Depending on which argument is supported, drastically different implications will ensue. If no relationship is found, the irrelevance criticism would be the likely explanation. If a negative relationship is discovered, the profits-first criticism would be supported, implying that MBA education erodes students' sense of moral and social responsibility. Finally, if the relationship is positive, MBA education could be said to actually have a positive outcome for all stakeholders involved (i.e., triple bottom-line) and would at the very least refute some of the irrelevance criticisms. Given the divergence of possibilities, we do not offer a formal hypothesis, but rather pose a research question to be subjected to empirical analysis:

Research Question: What is the relationship between CEO MBA education and $C E P$ ?

\section{METHOD}

\section{Sample and Data Sources}

The sample consisted of S\&P 500 firms and CEOs from 2004. Because the research question in this study involves CEOs' long-term influence over firm outcomes, CEOs with tenure of less than 1 year ( $n=76)$ were removed, leaving a sample of 426 (two firms were led by dual CEOs). The sample was further reduced by cases of missing data $(n=I O)$, which left a final sample of 416 . The average CEO age was $56(\mathrm{SD}=6.9)$, average company tenure was 18.2 years $(\mathrm{SD}=11.7)$, and average tenure as CEO was 7.6 years $(\mathrm{SD}=6.8)$. In addition, the CEOs in our sample represented firms from 53 different industries based on their two-digit level SIC code.

Three independent data sources were compiled for empirical testing. First, we gathered CEP data from KLD Research and Analytics Inc., an independent investment research firm specializing in firm ratings of environmental. social. and governance performance for use in investment decisions. KI.D's ratings of CEP have become frequently employed within academic research (e.g., Coombs, \& Gilley, 2005; Johnson \& Greening, 1999; Turban \& Greening, 1996) for a variety of reasons. First, KLD tracks multiple indicators of both strength and concern for each firm's impact on the environment--as opposed to restricting environmental performance to a single domain, such as toxic releases (i.e., TRI). Researchers also employ the KLD ratings due to the decreased probability for reporting bias. KLD gathers data from multiple sources, including extensive inspection of public records, surveys, and even on-site facility inspections (Berman, Wicks, Koth, \& Jones, 1999). Not only is data gathered from multiple sources, but it is also gathered in a uniform fashion by knowledgeable individuals not affiliated with the focal firm so that ratings are applied consistently to all firms rated (Waddock \& Graves, 1997).

Second, all CEO biographical information (i.e., education, functional background, tenure) was obtained from Spencer Stuart--a global executive search firm. Spencer Stuart's data was compiled from the following sources: Marquis Who's Who in 
America; The Corporate Yellow Book; 50,000 Leading U.S. Corporations-Business Trends; Standard and Poor's Register of Corporations, Directors and Executives; QuestNT (Spencer Stuart's proprietary database); corporate websites and press releases; company proxies; OneSource.com; Hoovers.com; and information requests directly to the firm when necessary.

Finally, firm-level performance data (industry classifications, firm size, and prior financial performance) were retrieved from COMPUSTAT. The data from KLD, Spencer Stuart. and COMPUSTAT were merged and analyzed for testing this study's research question.

\section{Measures}

\section{CEP}

KLD's index includes multiple dichotomous indicators of environmental "strengths" and "concerns." Strength items include production of environmentally beneficial products, pollution prevention, use of recycled materials, use of clean energy, and "other" proactive environmental activities. The concern items include hazardous waste practices, regulatory compliance, production of ozone depleting and agricultural chemicals, emissions, and other environmental controversies. The concern items were reversed coded, and all items were aggregated into a composite variable representing CEP (Coombs \& Gilley, 2005; Johnson \& Greening, 1999; Turban \& Greening, 1996; Waddock \& Graves, 1997). To help alleviate concerns of extreme yearly fluctuations, we calculated this composite for both 2003 and 2004. Given the high intercorrelation $(a=$ .83) we aggregated the 2003 and 2004 composite to form our CEP measure. As an index, a higher score indicates a firm possesses a greater number of CEP indicators while lower scores indicate lesser CEP.

\section{CEO MBA Education}

The CEO's attainment of an MBA was measured as a categorical variable indicating their possession of an MBA degree or lack thereof.

\section{Control Measures}

In order to rule out possible alternative explanations for any discovered relationship, several control variables were included in our analysis. These variables were selected based on prior research findings and to rule out potential confounds with the present study.

\section{CEO Functional Background}

CEO functional backgrounds, specifically outputoriented work experience (e.g., marketing, sales) have been shown to influence decision making and firm outcomes including social outcomes (e.g.. Slater \& Dixon-Fowler, 2009). Therefore, functional backgrounds were controlled by coding backgrounds as either output (e.g.. marketing, sales) or throughput (e.g., engineering, operations) based on Hambrick and Mason's classification (1984).

\section{CEO Age and Tenure}

The age of the CEO was included as a control variable. In addition, the number of years as CEO was used as a control measure for CEO tenure.

\section{CEO Education Level}

An argument could be made that any effects from MBA education on CEP are actually the effects of education in general instead of the specific effects of an MBA. Therefore, a variable was created to account for the level of educational attainment by the CEO. The measure ranged from 0 to 3 with a 0 indicating no college degree (9 CEOs; $2.2 \%$ of the sample); a 1 indicating the CEOs highest educational attainment was a bachelors degree (139 CEOs; 33.4\%); 2 indicating the CEO's highest educational attainment was a master's degree (198 CEOs; $47.6 \%)$; and 3 indicating the attainment of a doctorate degree (70 CEOs; $16.8 \%$ ).

\section{Industry CEP, Firm Size, and Prior Financial Performance}

Industry was controlled by using the CEP industry average based on the 2-digit SIC code. Firm size was measured using the natural $\log$ of sales for each firm. Prior firm financial performance was measured using the return on assets (ROA) from 2003 for each firm.

\section{Analysis and Results}

Table 1 provides means, standard deviations. and bivariate correlations for each variable. As a preliminary examination of the research question, CEO MBA education is found to have a significant and positive correlation with CEP $(\mathrm{r}=.10 ; p<.05)$. Table 2 provides additional detail. Demonstrating that the mean CEP is greater for firms with a CEO possessing an MBA than for firms with a CEO without an MBA.

Given the categorical nature of the independent 
TABLE 1

Descriptive Statistics and Correlations $(\mathrm{N}=416)$

\begin{tabular}{|c|c|c|c|c|c|c|c|c|c|c|}
\hline Variable & $M$ & $S D$ & & 2 & 3 & 4 & 5 & 6 & 7 & 8 \\
\hline 1. CEP & 2.79 & 69 & & & & & & & & \\
\hline 2. CEO MBA Education & .41 & .49 & $.10^{*}$ & & & & & & & \\
\hline 3. CEO Age & SS.96 & 6.93 & -.04 & $-.13 * *$ & & & & & & \\
\hline 4. CEO Tenure & 7.62 & 6.77 & .091 & -.091 & $.44 * *$ & & & & & \\
\hline S. CEO Education Level & 1.80 & .74 &.$- \mathrm{OS}$ & $.30 * *$ & $.16 * *$ & .03 & & & & \\
\hline 6. CEO Functional Background & .30 & .46 &.$- \mathrm{OS}$ & .04 & $-.22 * *$ & $-.18 * *$ & -.07 & & & \\
\hline 7. Industry CEP & 2.88 & .20 & $.38 * *$ & .03 & -.08 &. $\mathrm{OS}$ & -.03 & .091 & & \\
\hline 8. Firm Size & 8.86 & 1.19 & $-.2 \mathrm{~s} \cdots$ & .02 & .12 &.$- \mathrm{OS}$ & -.01 & -.02 & $-.24 * *$ & \\
\hline 9. Prior Financial Performance & .04 & .07 & .10 & $-.14 * *$ & .06 & $.10 *$ & -.06 & $.11^{*}$ &. $\mathrm{OS}$ & -.02 \\
\hline
\end{tabular}

${ }^{1} p<.10 .{ }^{*} p<$. OS. $\bullet p<.01$ (two-tailed).

variable and the necessity of controls, an ANCOVA was deemed the appropriate formal test of the research question. ANCOVA allows us to determine the variance explained by the categorical variable of interest (i.e., MBA-educated CEOs) af ter accounting for several firm- and individual-level characteristics. Table 3 includes the ANCOVA results, including the significance and effect sizes $\left(11^{2}\right)$ for each variable. Of the control variables included, industry. firm size. prior financial performance, and CEO functional background had a significant effect $(p<$.OS). while CEO age, tenure, and education level were not significant $(p>.10)$. The independent variable of interest. CEO MBA education, was found to have a signif icant effect $(p<.05)$. Thus, CEO MBA education has a signif icant and positive association with CEP.

We also ran the same ANCOVA on the 2003 and 2004 CEP composites separately and found the same pattern of results for the effect of MBA education on $2003 \mathrm{CEP}(F=8.720 ; p=.003)$ and 2004 $\mathrm{CEP}(F=5.438 ; p=.020)$.

\section{Post-Hoc Analyses}

Given the significant positive result, we elected to conduct additional analyses based on the assertion by critics that any positive effects of MBA education are not the result of MBA education itself, but rather result from the recruiting. screening. and networking of top-ranked programs (Pfef fer \& Fong, 2002). This assertion suggests that

IABLE 2

CEP Means, Standard Deviations, and Sample Sizes

\begin{tabular}{lccc}
\hline & $M$ & $S D$ & $n$ \\
\hline CEP for CEO with MBA & $2.86 \mathrm{~S}$ & 0.611 & 170 \\
CEP for CEO without MBA & 2.730 & 0.722 & 246 \\
\hline
\end{tabular}

MBAs from highly ranked programs should yield significantly greater benefits than MBAs from lower or un-ranked programs. due to their candidate selection.

The BusinessWeek rankings from 1988 were used as our measure of MBA program ranking. Given the average age of our sample (56), most of the CEOs attended their MBA programs prior to 1988 . However, the first available rankings from 1988 were used, based on research demonstrating their extremely high stability over time (Morgeson, \& Nahrgang. 2008). Using the same control variables included in Table 3, an ANCOVA was used to compare the CEP of firms whose CEO had an MBA from a top-10 program $(n=74)$ to firms whose CEO had an MBA from outside the top-10 programs $(n=96)$. The results showed no signif icant diff erence in CEP $(F=.003 ; p=.960)$. This analysis was extended comparing MBAs from top-20 programs $(\mathrm{n}=$ $100)$ to MBAs outside the top $20(\mathrm{n}=70)$ and still found no significant difference $(F=.814 ; p=.368)$. Finally. to assess if there were diff erences in CEP within the firms whose CEO had an MBA from a top-20 program $(n=100)$. the same control variables were included in a regression analysis and

TABLE 3

ANCOVA Results for CEP

\begin{tabular}{lccc}
\hline \multicolumn{1}{c}{ Variable } & \begin{tabular}{c} 
\\
\multicolumn{1}{c}{ Value }
\end{tabular} & $p$ Value & T12 \\
\hline Industry CEP & Sl.988 & .000 & .113 \\
Firm Size & $13.9 \mathrm{~S} 8$ & .000 & .033 \\
Prior Financial Performance & $4 . \mathrm{S} 07$ & .034 & .011 \\
CEO Age & .002 & $.96 \mathrm{~S}$ & .000 \\
CEO Tenure & 1.061 & .304 & .003 \\
CEO Education Level & 2.423 & .120 & .006 \\
CEO Functional Background & 4.088 & .044 & .010 \\
CEO MBA Education & $7.36 \mathrm{~S}$ & .007 & .018 \\
\hline
\end{tabular}

$\mathrm{R}^{2}=.203$

Adjusted R2 $=.187$. 
the top-20 rankings were used as the independent variable. Again, no significant effect was found for the program rankings $(\mathrm{t}=.466 ; p=.642)$.

One other post-hoc analysis was also conducted. While many control variables were included in the original analyses, a significant additional concern remains-reverse causality. It could be that high CEP firms are selecting CEOs with MBAs or that CEOs with MBAs are self-selecting into firms with higher CEP. To explore this possibility, we obtained KLD data from 1991 (first available year of KLD data) through our primary analysis year (2004) and acquired each $\mathrm{f}$ irm's CEP score on the year in which the CEO took office. The sample size for this analysis $(n=268)$ was reduced for two reasons: Some CEOs had start dates which preceded 1991, and many of the firms rated by KLD in 2004 were not rated by KLD in prior years. Using our sample of 268, a $t$ test revealed no significant difference in the hiring year CEP $(\mathrm{t}=-.158 ; p=.874)$ based on incoming CEOs with an MBA $(n=114)$ and those without $(n=154)$.

\section{DISCUSSION}

Our purpose in this study was to address the concern that MBA education teaches "ecologically unsound tactics that may bring planetary suicide" (Giacalone \& Thompson, 2006: 268). To this end, we considered multiple criticisms of MBA education and multiple perspectives on CEP. A review of the literature resulted in three possible propositions (i.e., no relationship, positive, and negative), and thus, the question of how MBA-educated CEOs might influence their firms' CEP was subjected to an empirical test. The results of this study suggest that CEOs with MBAs have a positive influence on CEP. Even after accounting for $\mathrm{f}$ irm characteristics (industry, size, and prior financial performance) and individual-level characteristics (age, tenure, functional background, level of education) we still found that CEO MBA education resulted in higher levels of CEP. Moreover, our post-hoc analysis revealed no significant differences in results when MBA program rankings were considered. This is contrary to claims by critics that MBAs from toptier programs may be associated with more meaningf ul outcomes due to differences such as candidate quality and program selectivity (Pfeffer \& Fong, 2002). Our results imply that consistency in MBA curricula across programs (Porter \& McKibbin, 1988) leads to similar CEP-related effects, regardless of the school's ranking, which reinforces the claim that it is the MBA training itself making a difference. Finally, additional post-hoc analysis revealed that CEOs with MBAs do not appear to self-select into firms with higher CEP nor are firms with higher CEP more likely to hire CEOs with MBA education. As important. this finding strengthens the results of this study by addressing the concern of reverse causality. Taking all analyses into consideration, this study suggests that CEOs with MBAs are positively associated with CEP and that this association is not the result of firm-level characteristics, individual-level characteristics, MBA program ranking, self-selection, or selection criteria. Instead, these findings suggest that the CEO's MBA education itself has a positive influence on their firm's CEP.

\section{Implications}

Our findings have important implications for a variety of stakeholder groups, including educators, business, and society. For educators and MBA administrators, our findings suggest that there is a benefit to an MBA education, contradicting the prominent criticism that MBA programs are irrelevant (Mintzberg, 2004; Pfeffer \& Fong, 2002). While we are unable to ref ute specific issues, such as the lack of sof $t$ skills training and functional silos, this study does suggest that there is an effect of MBA education. In addition, contrary to other studies which have found effects of business education (e.g., Frank \& Schulze, 2000; Williams, Barrett, \& Brabston, 2000), this outcome is positive. CEOs with MBAs are making a positive contribution to the environmental sustainability of our planet. However, while the positive outcome discovered in this study may be encouraging, we must also recognize that our findings appear consistent with the profits-first criticism prevalent in the literature. Unfortunately, we were unable to directly test the motivation of these CEOs for pursuing CEP (i.e., normative or business-case); however, based on our review of MBA education literature, we are not optimistic that the motivation extends beyond wealth creation. The MBA curricula is rooted in a long history of agency and transaction-cost perspectives, which create an "organization-centered worldview" (Giacalone \& Thompson, 2006), and if sustainability is taught at all, it is primarily from an economic standpoint. Given that students' moral philosophy doesn't appear to change during their time in business school (Neubaum et al.. 2009), the more plausible explanation is that MBAs have greater recognition of the economic benefits of CEP (e.g., greater levels of innovation; cost savings through efficiency gains; reputational advantages) and thus increase CEP solely in pursuit of profits. In other words, CEOs with MBAs most likely seek what they perceive as win-win situa- 
tions by pursuing only CEP activities that have a significant and perhaps immediate impact the firm's bottom line. These select CEP-oriented activities are not necessarily those that result in the largest environmental impact but may instead be the "low-hanging fruits" that are most likely to increase profitability. If so, these CEOs may pursue short-term profitability gains through CEP initiatives that are relatively easy and inexpensive to implement without regard for reducing the longterm environmental footprint of their firms.

Therefore, while MBA education has an influence over graduates' pursuit of CEP, perhaps we should ask whether that influence could be expanded to impact students' ethical decisions and sense of social responsibility and not simply the business case for social initiatives. As educators, socialized and trained according to this same paradigm, MBA professors may be uncomfortable integrating "moral based" arguments into business courses. Further, educators may feel that doing so jeopardizes one's reputation as well as the legitimacy of our discipline and should be left to educators in other disciplines (i.e., liberal arts) where such normative-based discussions have been traditionally viewed as more appropriate. As a result. even subject matters such as environmental sustainability, laden with normative implications, are more of ten taught in MBA courses from an economiccentered viewpoint (Giacalone \& Thompson, 2006), focusing on overarching questions such as "When does it pay to be green?" without asking students to also consider, "What is the 'right' thing to do?" On one hand, our results suggest that MBA programs make a difference by promoting a profitsfirst mentality, which leads to higher CEP. On the other hand, this does not mean that there isn't more to do in education around business and environmental sustainability. We are not advocating a dismissal of the business-case perspective for social issues, but rather a balance. Given that environmental sustainability is inherently a complex multifaceted issue, educators may consider if both CEP perspectives (i.e., normative and businesscase) are necessary for critical discourse and should be integrated into MBA curriculum.

The results of this study also have important implications for business. As a result of regulatory changes, stakeholder pressures, and recognition of potential competitive opportunities, firms are increasingly recognizing the importance of environmental issues in strategy formulation and decision making (Bansal \& Roth, 2000; Elkington, 1994; Hart. 1995). Given the $\mathrm{f}$ indings of this study, environmentally conscientious firms and firms concerned with the competitive advantages of CEP may want to consider the education of their executives. Specif ically, firms may consider implementing MBA tuition-assistance programs for employees or actively selecting and promoting managers with MBAs in pursuit of such efforts.

Finally, this study also has important societallevel implications. Given that the practices of large companies can significantly impact the natural environment (Samuelson, 2006), sustainability imperatives require that managers of these firms make decisions that do not compromise the ability of future generations to meet their own needs. Environmental sustainability is an important issue for the long-term viability of all organizations given that issues such as drinking water, clean air, and safe food are necessities for all stakeholders (e.g., employees, customers). Our results imply that through CEP, MBA programs have an important positive impact on environmental sustainability, and thus society as a whole.

\section{Limitations and Future Research}

This study is not without limitations. First, while we did find a positive relationship between CEO MBA education and CEP, we were unable to directly test the CEO's motivation or provide a definitive explanation for the MBA-CEP correlation. Based on the existing literature, there is very little support for a normative motivation and extensive support for the business case as a motivator. As such, we believe that MBAs are more likely than non-MBAs to recognize the instrumental benefits of CEP. However, other possibilities remain. Perhaps MBA courses that teach stakeholder theory (e.g., organizational theory) lead to an increased focus on environmental stakeholder needs. Alternatively, there may be a diffusion of environmental practices within the social networks of MBA students and alumni, which facilitates the CEO's ability to pursue CEP. Thus, future research may explore whether MBA-educated CEOs pursue CEP out of moral obligation, for financial gain, due to a focus on stakeholders, through their social networks, some combination, or due to other factors which we have not yet considered.

The possibility also remains that a third variable could account for our discovered relationship. For example, perhaps there is a personality variable which leads to pursuit of both MBA education and CEP. Or perhaps one's socioeconomic background has differential influence on these outcomes. While our analyses controlled for a number of alternative individual, educational, and firm-based explanations for our findings, the possibility remains that there is an additional psychological or 
sociological variable not being captured in the current model. Thus, the underlying microprocesses which influence the MBA CEO's decision making regarding $\mathrm{CEP}$ remain in question. By finding the first evidence of a link between MBA education and CEP we have provided a foundation for future studies to utilize experiments, questionnaires, or interviews of CEO MBAs in order to help open this black box and provide important insights.

This study is also limited by its measure of CEP. The KLD index utilizes multiple indicators, a wide variety of sources, is more comprehensive, and was intentionally selected over other commonly used and more narrow indicators of CEP (e.g., TRI). However, the multifaceted and complex construct of CEP is admittedly difficult to fully capture, and although scholars have pointed to the strengths of the KLD ratings (Berman, Wicks, Koth, \& Jones, 1999; Waddock \& Graves, 1997), critics have also questioned the reliability and validity of its data (e.g., Entine, 2003) and its lack of a weighting scheme for the various dimensions (Graves \& Waddock. 1994). Therefore, we may not have fully captured the broad range of activities that contribute to $\mathrm{CEP}$ in this study. Future research may utilize other sources or measures of CEP to replicate the findings presented here.

The nature of our sample also limits the generalizability of our findings. First. the majority of CEOs in our sample earned MBA degrees from U.S.-based institutions, and the firms in our sample are all based in the United States. It is feasible that MBA programs in other national contexts, particularly more collectivist-oriented countries, may have differential effects on CEP. Future crosscultural studies would help us better understand these potential differences. In addition, while we know that MBA education has influence long after an individual completes a program (e.g., Williams et al., 2000), most of the CEOs in our sample completed MBA programs 25-30 years ago, which may have a different influence than MBA education today. However, prior research suggests that MBA content and curriculum has become institutionalized and has not significantly changed since the 1960s (Davis \& Botkin, 1994). Even with the increasing emphasis on environmental issues, only $7 \%$ of MBA students indicate that their universities of fer relevant environmental management-related courses among core offerings (DiMeglio, 2005), suggesting that MBA programs respond to change relatively slowly. Nevertheless, some schools are beginning to integrate sustainability into the core curriculum (DiMeglio, 2005). The question of how this curriculum will be presented, however, re- mains to be seen. Yet. it is possible that the nature of the MBA-CEP relationship may change in the future, particularly if more normative perspectives are introduced.

\section{CONCLUSION}

MBA programs have been the subject of a long line of criticisms claiming that MBA education is irrelevant (e.g., Dreher et al., 1985; Ghoshal. 2005; Leonhardt. 2000; Mintzberg, 2005; Pfeffer \& Fong, 2002) or results in a "profits-first" mentality, which has contributed to opportunism and unethical decision making (e.g., Ghoshal. 2005; Giacalone \& Thompson, 2006). In contrast. we demonstrate a significant positive relationship between CEOs with MBAs and CEP. While addressing the concern over a lack of empirical research focusing on criticisms of MBA education (Pfeffer \& Fong, 2002), these results provide meaningful insights and a new perspective into the long-standing debate regarding whether MBAs matter. Further, while most prior research focuses on individual-level outcomes of MBA education (e.g., compensation), this study addresses an important firm-level outcome with implications for global sustainability.

The empirical results presented here refute the irrelevance criticism of MBA education, which should serve as an encouragement to educators by providing a glimmer of hope to what has become a very dark view of MBA programs. These results suggest that educators are making a difference and that MBA programs do matter. However, the most likely interpretation of the results also lends some support to the profits-first criticism of MBA education and suggests that MBA graduates pursue a "moral" cause with a material motivation. Thus. these results should not serve as a sign that all is well with MBA education. Instead, these results should serve as an encouragement that MBA education makes a difference, but also that much room for improvement remains.

\section{REFERENCES}

Agle, B. R., Mitchell, R. K., \& Sonnenfeld, J. A. 1999. Who matters to CEOs? An investigation of stakeholder attributes and salience, corporate performance and CEO values. Academy of Management Journal. 42(5): 507-525.

Aragon-Correa, J. A. 1998. Strategic proactivity and firm approach to the natural environment. Academy of Management Journal. 41(5): 556-567.

Bansal. P., \& Clelland, I. 2004. Talking trash: Legitimacy, impression management, and unsystematic risk in the context of the natural environment. Academy of Management Journal. 47: 93-103.

Bansal. P., \& Roth, K. 2000. Why companies go green: A model of 
ecological responsiveness. Academy of Management Journal, 43(4): 717-736.

Benn, S., \& Dunphy, D. 2009. Action research as an approach to integrating sustainability into MBA programs. Journal of Management Education, 23(3): 276-295.

Bennis, W. G., \& O'Toole, J. 2005. How business schools lost their way. Harvard Business Review, 93(5): 96-104.

Berman, S. L., Wicks, A. C., Koth, S., \& Jones, T. M. 1999. Does stakeholder orientation matter? The relationship between stakeholder management models and firm financial performance. Academy of Management Journal, 42: 488-506.

Bowen, H. R. 1953. Social responsibilities of the businessman. New York: Harper \& Row.

Carroll, A. B. 1979. A three-dimensional conceptual model of corporate social performance. Academy of Management Review, 4: 497-505.

Carter, J. R., \& Irons, M. D. 1991. Are economists different, and if so, why? Journal of Economic Perspectives, 5: 171-177.

Cerio, S. T., Lester, R. H., Dalton, C. M., \& Dalton, D. R. 2006. Top management teams, strategy, and financial performance: A meta-analytic examination. Journal of Management Studies, 43(4): 813-839.

Coase, R. H. 1960. The problem of social cost. Journal of Law and Economics, 3: 1-44

Coombs, J. E., \& Gilley, K. M. 2005. Stakeholder management as a predictor of CEO compensation: Main effects and interactions with financial performance. Strategic Management Journal, 26: 827-840.

Davis, S., \& Botkin, J. 1994. The monster under the bed: How business is mastering the opportunity of knowledge for profit. New York: Simon and Schuster.

DiMaggio, P. J., \& Powell, W. W. 1983. The iron cage revisitedInstitutional isomorphism and collective rationality in organizational fields. American Sociological Review, 48(2): 147-160.

Di Meglio F. 2005. Its getting easier to be green. BusinessWeek. Retrieved from www.businessweek.com.

Dixon-Fowler, H. R., Slater, D. J., Romi, A., Johnson, J., \& Ellstrand, A. 2009. Beyond "does it pay to be green?" A metaanalysis of moderators of the CEP and CFP relationship. Presented at the annual meeting of the Academy of Management, Chicago, IL.

Donaldson, T., \& Preston, L. E. 1995. The stakeholder theory of the corporation: Concepts, evidence, and implications. Academy of Management Review, 20: 65-91.

Dreher, G. F., Dougherty, T.W., \& Whitely, B. 1985. Generalizability of MBA degree and socioeconomic effects on business school graduates' salaries. Journal of Applied Psychology, 70: 769-773

Elkington, J. 1994. Towards the sustainable corporation-Winwin-win business strategies for sustainable development. California Management Review, 36(2): 90-100.

Entine, J. 2003. The myth of social investing: A critique of its practice and consequences for corporate social performance research. Organization \& Environment, 16(3): 352368.

Evans, F. J., \& Robertson, J. 2003. Ethics in the business curriculum: A survey of deans in AACSB schools. Business and Society Review. 110(3): 233-248.
Evans, J. M., Trevino, L. K., \& Weaver, G. R. 2006. Who's in the ethics driver's seat? Factors influencing ethics in the MBA curriculum. Academy of Management Learning \& Education, 5(3): 278-293.

Frank, B., \& Schulze, G. G. 2000. Does economics make citizens corrupt? Journal of Economic Behavior and Organization, 43: $101-113$

Frank, R. H., Gilovich, T. D., \& Regan, D. T. 1993. Does studying economics inhibit cooperation? Journal of Economic Perspectives, 7: 159-171.

Frederick, W. C. 1960. The growing concern over business responsibility. California Management Review, 2: 54-61.

Freeman, R., \& Evan, W. 1990. Corporate governance: A stakeholder interpretation. Journal of Behavioral Economics, 19(4): 337.

Ghosha!, S. 2005. Bad management theories are destroying good management practices. Academy of Management Learning \& Education, 4(1): 75-91.

Giacalone, R. A., \& Thompson, K. R. 2006. Business ethics and social responsibility education: Shif ting the worldview. Academy of Management Learning \& Education, 5(3): 266277.

Graves, S. B., \& Waddock, S. A. 1994. Institutional owners and corporate social performance. Academy of Management Journal, 37(4): 1034-1046.

Hambrick, D. C., \& Mason, P. A. 1984. Upper echelons: The organization as a reflection of its top managers. Academy of Management Review, 9(2): 193-206.

Hart. S. L. 1995. A natural-resource-based view of the firm. Academy of Management Review, 20(4): 986-1014.

Henle, C. A. 2006. Bad apples or bad barrels? A former CEO discusses the interplay of person and situation with implications for business education. Academy of Management Learning \& Education, 5(3): 346-355.

Hosmer, L. T. 1982. The importance of strategic leadership. The Journal of Business Strategy 3(2): 47-58.

Jenkins, R. L., \& Reizenstein, R. C. 1984. Insights into the MBA: Its contents, output, and relevance. Selections, 2: 19-24.

Johnson, R. A., \& Greening, D. W. 1999. The effects of corporate governance and institutional ownership types on corporate social performance. Academy of Management Journal, 42: 564-576.

Jones, T. M. 1995. Instrumental stakeholder theory: A synthesis of ethics and economics. Academy of Management Review, 20: 404-437.

Jones, T. M., \& Wicks, A. C. 1999. Convergent stakeholder theory. Academy of Management Review, 24(2): 206-221.

Klassen, R. D., \& McLaughlin, C. P. 1996. The impact of environmental management on firm performance. Management Science, 42(8): 1199-1214.

Leavitt, H. J. 1989. Educating our MBAs: On teaching what we haven't taught. California Management Review, 31(3): 3850 .

Leonhardt, D. 2000. A matter of degree? Not for consultants. New York Times, October 1, 2000, Section 31: 1-18.

Lewicki, R. J. 2005. Jerry Jurgenson, chief executive officer of Nationwide, on Mintzberg's Managers Not MBAs. Academy of Management Learning \& Education, 4(2): 240-243.

Madagan, P. 2008. Organizations and responsibility: A critical 
overview. Systems Research and Behavioral Science, 25(3): 371-381.

Marwell, G.. \& Ames, R. E. 1981. Economists free ride, does anyone else? Journal of Public Economics, 15: 295-310.

McCabe, D. L., Butterfield, K. D.. \& Trevino, L. K. 2006. Academic dishonesty in graduate business programs: Prevalence, causes, and proposed action. Academy of Management Learning \& Education, 5(3): 294-305.

McCabe, D. L.. \& Trevino, L. K. 1995. Cheating among business students: A challenge for business leaders and educators The Journal of Management Education, 19(2): 205-218.

Meyer, J. W.. \& Rowan, B. 1977. Institutionalized organizationsFormal-structure as myth and ceremony. American Journal of Sociology, 83(2): 340-363.

Mintzberg, H. 1978. Patterns in strategy formation. Management Science, 24(9): 934-949.

Mintzberg, H. 2004. Managers not MBAs: $A$ hard look at the soft practice of managing and management development. San Francisco: Berrett-Koehler.

Mintzberg, H. 2005. The magic number seven-plus or minus a couple of managers. Academy of Management Leaming and Education, 4(2): 244-247.

Mitroff, I. I. 2004. An open Jetter to the deans and the faculties of American Business Schools. Journal of Business Ethics, 54: 185-189.

Margeson, F. P.. \& Nahrgang, J. D. 2008. Same as it ever was: Recognizing stability in the BusinessWeek rankings. Academy of Management Learning \& Education, 7(1): 26-41.

Navarro, P. 2008. The MBA core curricula of top-ranked U.S. business schools: A study in Failure? Academy of Management Leaming \& Education, 7(1): 108-123.

Neubaum, D. 0.. Pagell, M.. Drexler, J.A., Jr., McKee-Ryan, F. M., \& Larson, E. 2009. Business education and its relationship to student personal moral philosophies and attitudes towards profits: An empirical response to critics. Academy of Management Leaming \& Education, 8(1): 9-24.

Orlitzky, M., Schmidt, F. L., \& Rynes, S. L. 2003. Corporate social and financial performance: A meta-analysis. Organization Studies. 24(3): 403-441.

Pejovich, S. 1990. The economics of property rights: Toward a theory of comparative systems. Dordrecht, The Netherlands: Kluwer Academic Publishers.

Pfeffer, J., \& Fong, C. T. 2002. The end of business schools? Less success than meets the eye. Academy of Management Leaming \& Education. 1(1): 78-95.

Porter, L. W., \& McKibbin, L. E. 1988. Management education and development: Drift or thrust into the 21st century. New York: McGraw-Hill.

Porter, M. D.. \& Kramer, M. R. 2006. Strategy \& society: The link between competitive advantage and corporate social responsibility. Harvard Business Review, 84(12): 78-92.

Porter, M. E., \& van der Linde, C. 1995. Toward a new conception of the environment-competitiveness relationship. Journal of Economic Perspectives, 9(4): 97-118.

Rubin, R. S., \& Dierdorf. E. C. 2009. How relevant is the MBA? Assessing the alignment of required curricula and required managerial competencies. Academy of Management Learning \& Education, 8(2): 208-224.

Samuelson, J. 2006. The new rigor: Beyond the right answer. Academy of Management Leaming \& Education, 5(3): 256365 .

Simerly, R. L. 2003. An empirical examination of the relationship between management and corporate social performance. International Journal of Management. 20(3): 353-359.

Simpson, R. 2006. Masculinity and management education: Feminizing the MBA. Academy of Management Education \& Learning. 5(2): 182-193.

Slater, D. J., \& Dixon-Fowler, H. R. 2009. CEO international assignment experience and corporate social performance. Journal of Business Ethics, 89(3): 473-489.

Turban, D., \& Greening, D. 1996. Corporate social performance and organizational attractiveness to prospective employees. Academy of Management Journal, 40(3): 658-672.

Waddock, S. A., \& Graves, S. B. 1997. The corporate social performance-financial performance link. Strategic Management Journal, 18: 303-319.

Welford, R. J., \& Gouldson, A. 1993. Environmental management and business strategy. London: Pitman Publishing.

Williams, R. J., Barrett, J. D., \& Brabston, M. 2000. Managers' business school education and military service: Possible links to corporate criminal activity. Human Relations. 53: 691-712.

Wood, D. J. 1991. Corporate social performance revisited. Academy of Management Review. 16(4): 691-718.

World Commission on Economic Development. 1987. Our common future. Oxford: Oxford University Press.

Daniel J. Slater (PhD, University of Arkansas, dslater@uu.edu) is an assistant professor of management in the McAfee School of Business Administration, Union University. Slater's current research focuses on the intersection between upper echelons theory and methodologies and social outcomes, such as corporate social and environmental performance.

Heather R. Dixon-Fowler (PhD, University of Arkansas, dixonfowlerh@appstate.edu) is an assistant professor of management at the Walker College of Business, Appalachian State University. Dixon-Fowler's current research interests include corporate governance and corporate social and environmental performance. She is particularly interested in how the characteristics of the firm's leaders influence the social responsibility strategies of their organizations. 